\title{
Academic Stress and Coping Strategies of High School Students with Single-Parents in Antique
}

\author{
Kenia Hukom ${ }^{1}$ and Dennis V. Madrigal ${ }^{2}$ \\ ${ }^{1}$ Saint Joseph Academy Inc., Bugasong, Antique, Philippines \\ ${ }^{2}$ University of Negros Occidental-Recoletos, Bacolod City, Philippines
}

\begin{abstract}
Article history
Submitted: 30 June 2020

Revised: 28 October 2020

Accepted: 13 November 2020

Keywords

Guidance and Counseling

Academic Stress

Coping Strategies

High School Students

Catholic School

Descriptive-Correlational

Antique
\end{abstract}

Introduction. Today, stress is growing day by day among students with single-parents, yet the basic concepts to minimalize, endure, and master the stress are often ignored. In many places around the world, students experienced significant academic distress, and being unaware of how to deal with it is a serious concern, which worsens the schoolsetting situation. Education and social support systems are prime movers in developing and enriching students, particularly in adopting appropriate coping strategies. Hence, this paper describes the level of academic stress and the extent of coping strategies of high school students with single-parents in a Catholic School in Antique during the school year 2019-2020. Likewise, it explores the relationship existing between the students' demographics and their academic stress and coping strategies.

Methods. A descriptive-correlational research design was used to assess the level of academic stress and extent of coping strategies of high school students with single-parents of Catholic School in Antique during the school year 2019-2020. Through simple random sampling, 67 students were selected to participate in the study. The data were gathered using a standardized instrument developed by Rao (2012) and Carver (1989). Mean, Standard Deviation, and Pearson Product Moment correlation were used to analyze the data.

Results. The findings of the study revealed that the level of academic stress of high school students with single-parent is generally low. When grouped according to demographics, students also showed a low level of academic stress regardless of their academic level and single-parents' educational level. However, a moderate level of academic stress was found when the grouping was in terms of sex and family monthly income. Also, it revealed that fear of failure is the highest source of academic stress. Likewise, the extent of coping strategies of high school students is great irrespective of academic level, sex, family monthly income, and single-parents' educational level. However, analyzing the mean values of family monthly income, the extent of coping of the high-income group was higher than of the low-income. Also, as a whole, the emotion-focused strategy of coping with stress is predominantly used by the students, while the avoidance-focused was the least one. As to the relationship between demographics and academic stress, the findings revealed that there is no significant relationship between academic level and single-parents' educational level. On the other hand, a significant relationship was found between academic stress and sex and family monthly income. As to the relationship between demographics and extent of coping, the findings revealed that there is no significant relationship between academic level, sex, and single-parents' educational level. On the other hand, there is a significant relationship between the extent of coping and family monthly income. Finally, no significant relationship was found between academic stress and coping strategies.

Conclusion. The school program on stress management is essential in fostering students' competence and ability to cope with life's stress and the strong desire to excel in academic-related endeavors during this new normal. The data showed a low level of academic stress; however, the academic demands of the educational system this new normal is quite taxing and challenging and were mostly accountable for students' higher level of stress. The program delivers different services to meet further and realize the needs of the students to become empowered in facing the adversities 
of life. Thus, the guidance designate and the teachers have a huge responsibility in creating programs to minimize academic stress and maximize the students' coping strategies. It is further shown that a low level of academic stress and a great extent of coping significantly are good indicators of school achievement. However, it may be better if that will be added by external elements such as social support that can offer a hand for accomplishing a specific task or outcome, for it may result in a greater and stronger force that will direct behavior towards a goal. It is also implied that guidance designate, teachers, and parents as prime movers can develop, build, and enrich students to excel in academic-related tasks. Their active participation and their presence in school-related activities and monitoring students' status add up to the students' successes, especially in attaining holistic transformation.

Practical Value of the Paper. The study significantly contributes to the existing literature and studies on the academic stress and coping strategies of students in Catholic schools

\section{References}

Akande, J. A., Olowonirejuaro, A. O., \& Okwara-Kalu, C. E. (2014). A Study of Level and Sources of Stress among Secondary School Students. IOSR Journal of Research \& Method in Education, 4(5), 32-36.

Carver, C. S., Scheier, M. F., \& Weintraub, J. K. (1989). Assessing coping strategies: A theoretically based approach. Journal of Personality and Social Psychology, 56, 267-283

Ghatol, S. D. (2017). Academic Stress among Higher Secondary School Students: A Review. Int J Adv Res Educ Technol (IJARET), 4(1), 38-41.

Krohne, H. W. (2002). Stress and Coping Theories. International Encyclopedia of the Social Behavioral Sciences, 22, 15163-15170.

Kumar, S. \& Jejurkar, K. (2005). Study of Stress Level in Occupational Therapy Students during their Academic Curriculum. The Indian Journal of Occupational Therapy, 37(1), 5-14.

Misra, R. \& Castillo, L. G. (2004). Academic Stress among College Students: Comparison of American and International Students. International Journal of Stress Management, 11(2), 132.

Porwal, K. \& Kumar, R. (2014). A Study of Academic Stress among Senior Secondary Students. The International Journal of Indian Psychology, 1(3), 133-137.

Prabu, P. S. (2015). A Study on Academic Stress among Higher Secondary Students. International Journal of Humanities and Social Science Invention, 4(10), 63-68

Rao, R.Balaji (2012). A study of academic stress and adjustment styles of teacher trainees. Scale of academic stress.235-237

Robotham, D. \& Julian, C. (2006). Stress and the Higher Education Student: A Critical Review of the Literature. Journal of Further and Higher Education, 30(02), 107-117.

Salami, S. O. \& Alawode, E. A. (2000). Influence of Single-parenting on the Academic Achievement of Adolescents in Secondary Schools: Implications for Counseling. Ibadan: Department of Guidance and Counseling University of Ibadan.

Sulaiman, T., Hassan, A., Sapian, V. M., \& Abdullah, S. K. (2009). The Level of Stress among Students in Urban and Rural Secondary Schools in Malaysia. European Journal of Social Sciences, 10(2), 179-184.

\section{Correspondence:}

Kenia Hukom [kenhukom1996@gmail.com]

http://orcid.org/0000-0001-6659-5797 